|| ISSN(online): 2589-8698 || ISSN(print): 2589-868X || International Journal of Medical and Biomedical Studies

Available Online at www.ijmbs.info

Volume 3, Issue 2; February: 2019; Page No. 47-49

PubMed (National Library of Medicine ID: 101738825)

Index Copernicus Value 2017: 40.03

\title{
STUDY TO FIND OUT THE EFFICACY OF 6 MINUTE WALK TEST IN ASSESSING RESPONSE TO MEDICAL INTERVENTION IN CHRONIC OBSTRUCTIVE PULMONARY DISEASE PATIENTS
}

\author{
Dinesh Gurjar ${ }^{1}$, Mukesh Gupta ${ }^{2}$, Harish Sharma ${ }^{3}$, Sunil Pathak ${ }^{4}$ \\ ${ }^{1}$ Senior Resident, ${ }^{2}$ Professor \& HOD, ${ }^{3,4}$ Associate Professor \\ Department of General medicine, Govt. Medical College, Bharatpur, Rajasthan
}

Article Info: Received 22 January 2019; Accepted 15 February. 2019

Cite this article as: Gurjar, D., Gupta, M., Sharma, H., \& Pathak, S. (2019). STUDY TO FIND OUT THE EFFICACY OF 6 MINUTE WALK TEST IN ASSESSING RESPONSE TO MEDICAL INTERVENTION IN CHRONIC OBSTRUCTIVE PULMONARY DISEASE PATIENTS. International Journal of Medical and Biomedical Studies, 3(2).

DOI: https://doi.org/10.32553/ijmbs.v3i2.93

Address for Correspondence: Mukesh Gupta, Professor \& HOD, Department of General medicine, Govt. Medical College, Bharatpur, Rajasthan

Conflict of interest: No conflict of interest.

\section{Abstract}

Background: Chronic obstructive pulmonary disease (COPD) is a lung condition which is a result of long term inflammation of the lung tissues, especially the airways. COPD manifests with respiratory symptoms like breathlessness, effort intolerance, cough with expectoration and in severe cases respiratory arrest, respiratory failure or heart failure.

Methods: We included 50 patients with stable COPD attending the outpatient department in the stipulated study period and diagnosis of COPD was established by clinical symptoms and spirometric data of ratio of FEV 1 and forced vital capacity (FVC) $\leq 0.7$.

Results: The 6 minute walk distance (6MWD) of the patients were assessed once the health status of the patients have been stabilized. This was done under strict monitoring, just before discharge of the patient from the hospital. Participants aged less than 60 years had a 6MWD of $342 \mathrm{~m}$ while those aged above 60 years clocked $291 \mathrm{~m}$. With regards to gender, males had significantly higher 6 MWD when compared to females.

Conclusions: 6MWT can be a useful replacement of spirometry in assessment of severity of COPD.

Key words: Chronic obstructive pulmonary disease, six-minute walk test, spirometric indices, severity

\section{Introduction:}

Chronic obstructive pulmonary disease (COPD) is a lung condition which is a result of long term inflammation of the lung tissues, especially the airways. COPD manifests with respiratory symptoms like breathlessness, effort intolerance, cough with expectoration and in severe cases respiratory arrest, respiratory failure or heart failure. The pathognomonic feature of COPD is the irreversible airway inflammation which is represented by a forced expiratory volume in 1 second/forced vital capacity ratio of less than 0.7. COPD is mostly caused by excessive smoking and often results in deterioration of the quality of living of the patients. ${ }^{1}$

Smoking cessation is the most important modality involved in control of COPDsymptoms. The mainstay of long term management is bronchodilators, and the choice between long 
acting adrenergic agents and anticholinergics depends on the patients' perception of improvement in symptoms. Inhaled corticosteriods are used as adjuvant therapy if the symptoms persist even after adequate use of bronchodilators. Pulmonary rehabilitation through behavioral changes and increase in exercise capacity is also a priority in management of chronic obstructive pulmonary disease. ${ }^{2}$ The accurate diagnosis of COPD has always been difficult due to the subjective nature of most investigations. Spirometry has been traditionally used as a method for diagnosis of COPD and also assessing the progression of disease and response to treatment. But American College of chest physicians and American thoracic society has recommended that spirometry should be used only in patients with respiratory systems and not for screening in apparently normal people. ${ }^{3}$ Spirometry is also considered as a hugely subjective test with low reproducibility. The spirometry results depend heavily on the quality of the equipment, cooperation of the patient and also skill of the technician performing the test. Also, spirometry is a medical test and it may not indicate the patients' ability to perform activities of daily living and therefore, this test may not accurately reflect the improvement following treatment. ${ }^{4}$ Other studies have shown that chronic obstructive pulmonary disease (COPD) is under diagnosed in primary care and the main reason is the under-utilization of spirometry. Cost of equipment, cumbersome testing procedure, lack of trained personnel and absence of a mobile testing equipment are cited as the main reasons for underutilization of spirometry in primary care settings. All this results in a delay in diagnosing the condition, making an early and effective intervention impossible. ${ }^{5}$

\section{METHODS}

This was cross-sectional observational study. We included 50 patients with stable COPD attending the outpatient department in the stipulated study period and diagnosis of COPD was established by clinical symptoms and spirometric data of ratio of $\mathrm{FEV}_{1}$ and forced vital capacity $(\mathrm{FVC}) \leq 0.7$.

We excluded patients who had clinical or radiological evidence of pneumonia, blood pressure $\geq 180 / 100 \mathrm{mmHg}$, and resting heart rate $>120 /$ min prior to $6 \mathrm{MWT}$, evidence of left ventricular failure (LVF), ischemic heart disease (IHD), or any major cardiac disease, neuromuscular disease of the lower extremities, peripheral vascular disease, and those who refused to give informed written consent for the study.

The 6 minute walk test ( $6 \mathrm{MWT}$ ) was performed in a secured 30 meter straight corridor, situated inside the hospital campus. The patients were instructed to walk from end to end at their own pace, attempting to cover as much distance as possible. The 6 minute walk distance ( $6 \mathrm{MWD}$ ) was the primary measurement during the test, and dyspnea as measured using modified BORG scale was the secondary measurement. Later spirometric evaluation was done for all participants, with measurement of forced expiratory volume in 1 second (FEV1) and forced vital capacity (FVC), before and after administration of an inhaled bronchodilatory agent. The respiratory health and health linked quality of life of the patients were assessed using St. George's respiratory questionnaire (SGRQ), an international accepted tool designed for this specific purpose.

\section{Results}

Table 1: Socio-demographic variable

\begin{tabular}{|l|l|l|}
\hline $\begin{array}{l}\text { Socio-demographic } \\
\text { variable }\end{array}$ & $\begin{array}{l}\text { No of } \\
\text { patients }\end{array}$ & Percentage \\
\hline Age & & \\
\hline$<60$ Yrs & 13 & 26.00 \\
\hline$\geq 60$ Yrs & 37 & 74.00 \\
\hline Gender & & \\
\hline Male & 44 & 88.00 \\
\hline Female & 6 & 12.00 \\
\hline
\end{tabular}

A total of 50 patients admitted with primary diagnosis of chronic obstructive pulmonary disease (COPD) were included in the study. A 
majority $(74.00 \%)$ of the participants were aged 60 years and above, and around $88.00 \%$ were males.

Table 2: Factor effected 6 minute walk distance

\begin{tabular}{|l|l|l|}
\hline Variable & $6 \mathrm{MWD}$ & P-value \\
\hline$<60$ Yrs & $342 \pm 23.3 \mathrm{~m}$ & 0.001 \\
\cline { 1 - 2 }$\geq 60$ Yrs & $291 \pm 21.8 \mathrm{~m}$ & \\
\hline Male & $312 \pm 20.86 \mathrm{~m}$ & 0.001 \\
\cline { 1 - 2 } Female & $256 \pm 19.8 \mathrm{~m}$ & \\
\hline
\end{tabular}

The 6 minute walk distance (6MWD) of the patients were assessed once the health status of the patients have been stabilized. This was done under strict monitoring, just before discharge of the patient from the hospital. Participants aged less than 60 years had a 6MWD of $342 \mathrm{~m}$ while those aged above 60 years clocked $291 \mathrm{~m}$. With regards to gender, males had significantly higher $6 \mathrm{MWD}$ when compared to females.

\section{Discussion}

The study was done on patients with chronic obstructive pulmonary disease (COPD) who had achieved cardiopulmonary stability. The 6 minute walk distance (6MWD) was the primary modality which was measured. Age was a significant factor which determined the $6 \mathrm{MWD}$, with participants below 60 years of age performing significantly better than those aged 60 or above. A similar trend was observed in other studies also, with a report from Japan showing poor performance indicators as age progress. ${ }^{6} \mathrm{~A}$ study done in Turkey also showed similar findings. ${ }^{7}$

\section{Conclusions}

6MWT can be a useful replacement of spirometry in assessment of severity of COPD

\section{References}

1. Delzell JE. Common lung conditions: chronic obstructive pulmonary disease. FP Essent. 2013;409:23-31.

2. Devillier $P$, Salvator $H$, Roche $N$, Grassin DS, Naline $E$, Dorocant $S$ et al. Long-term treatment strategy in chronic obstructive pulmonary disease: how to change the course of the disease. Presse Med. 2014;43(12):1368-80.

3. Qaseem $A$, Wilt TJ, Weinberger SE, Hanania NA, Criner G, Molen T, et al. Diagnosis and management of stable chronic obstructive pulmonary disease: a clinical practice guideline update from the American College of Physicians, American College of Chest Physicians, American Thoracic Society, and European Respiratory Society. Ann Intern Med. 2011;155(3):179-91.

4. Macintyre NR. Spirometry for the diagnosis and management of chronicobstructive pulmonary disease. Respir Care. 2009;54(8):1050-7.

5. Johns DP, Walters JAE, Walters EH. Diagnosis and early detection of COPD using spirometry. J Thorac Dis. 2014;6(11):1557-69

6. Fujimoto $H$, Asai $K$, Watanabe $T$, Kanazawa $\mathrm{H}$, Hirata K. Association of six-minute walk distance (6MWD) with resting pulmonary function in patients with chronic obstructive pulmonary disease (COPD). Osaka City Med J. 2011;57(1):21-9.

7. Gungor G, Karakurt Z, Adiguzel N, Aydin RE, Balci MK, Salturk C, et al. The 6-minute walk test in chronic respiratory failure: does observed or predicted walk distance better reflect patient functional status? Respir Care. 2013;58(5):850-7. 